\title{
Fra Atlanta over Sydney til Olympia - en atletisk Tour de Force tilbage til oldtiden af Thomas Skovgaard
}

\section{Indledning}

Vi er midt i en olympiade. Forstået på den måde, at vi er ved vendepunktet i en fireårs periode, der i den ene ende afgrænses af Coca-Cola legene i Atlanta og i den anden ende afsluttes down-under med Sydney år 2000.

Her, kort tid før nedtællingen for alvor går i gang til det, som stadig er The Greatest Sportsshow on Earth, kan det derfor være på sin plads at sætte focus på nogle af de mange spændende, morsomme og evigt aktuelle historiske samt idræts- og samfundsmæssige aspekter, der knytter sig til fænomenet De Olympiske Lege.

Opgaven på de følgende sider vil dog blive indsnævret til primært at dreje sig om en belysning af nogle af de mest centrale forhold i og omkring den institution, der om nogen opfattes som forløberen - eller måske rettere forbilledet - for megen af den moderne idræt og sport - nemlig De antikke Olympiske Lege.

Lige siden den tyske arkæolog Ernst Curtius for alvor begyndte sine udgravninger ved Olympia i 1875, har der fra mange sider været spekulationer i gang om, hvilke årsager der lå til grund for, at oldgrækerne $\mathrm{i}$ mere end et årtusinde fra 776 før vor tidsregning (f.v.t) til 393 efter vor tidsregning (e.v.t) valfartede til Olympia og denne helligdoms atletiske lege, samt hvorfor disse lege indtog den status de ubestrideligt gjorde $\mathrm{i}$ den antikke verden.

Det endegyldige svar på hvorfor netop De Olympiske Lege blev oldgrækernes idrætsbegivenhed par excellence vil nok altid stå hen i det uvisse, og problematikken er, i og for sig selv, heller ikke særlig interessant. Mere spændende er det at komme med nogle bud på, hvorledes en institution som De Olympiske Lege i en række sammenhænge, der rakte udover de rent idrætslige, fik så stor betydning for oldgrækerne. Såvel den olympiske historie som den sideløbende antikke historie er dog lang og knudret, og det er, som altid, begrænset hvad der kan gabes over på én gang. Denne artikel begrænser sig derfor til den periode, der dækker arkaisk og klassisk tid (d.v.s cirka 750-300 f.v.t). Iøvrigt koncentrerer fremstillingen sig om de politiske og religiøse funktioner som De Olympiske Lege havde i den pågældende periode.

Den første problemstilling, der melder sig, vokser ud af den meget rimelige diskussion af, hvorvidt der overhovedet er nogen rimelighed $\mathrm{i}$ at drage en parallel mellem den idræt, der blev dyrket i antikken, og så den moderne sport som den formede sig fra et eller andet sted i forrige århundrede. Man kan med megen ret hævde, at den moderne sport, og den tid hvori den har gjort sig, udgør en ganske særegen enhed. Den moderne sport udmærker sig ved sit fuldstændige areligiøse udgangspunkt 
samt sin forkærlighed for tal, tider og rekorder. På den anden side er det således, at en del af de idrætter, som i dag er paradediscipliner, ligeledes var det hos de gamle grækere, helt tilbage fra de første store kulturer på eksempelvis Kreta et par tusinde år f.v.t. Hvorvidt sporten er tidsløs, eller om den som begreb kun hører hjemme i allernyeste tid, ligger altså ikke fast.

Derimod er det helt åbenlyst, at der hos både lægfolk og professionelle historikere ofte sker en sammenblanding af den institution, som både $\mathrm{i}$ antikken og i moderne tid, har virket som kransekagefigur - De Olympiske Lege.

Påkaldelsen af en sammenhæng mellem det antikke og det moderne har fundet sted og er blevet styrket lige siden de første moderne lege blev afholdt i 1896 i Athen. I dag er det derfor stadig en udbredt misforståelse, at de moderne og antikke lege har andet og mere end navnet (og endda det kan diskuteres) til fælles.

Lad os kort se på et par eksempler på dette vrangbillede:

For det første bestræber arrangørerne af de moderne lege sig på at få så mange nationer som muligt til at deltage. Til forskel herfra lagde man i antikken megen vægt på, at kun græske borgere måtte deltage $\mathrm{i}$ denne begivenhed.

For det andet indbefattede begrebet »borger « kun mænd og drenge. Kvinder ville man altså ikke se på under idrætslegene $i$ antikken. Denne udelukkelse af det ene $k ø n$ var en funktion af den tilbagetrukne tilværelse, som de græske kvinder i al almindelighed levede i det antikke samfund. En af Athens største statsmænd, Perikles (492-429 f.v.t), gav udtryk for denne tingenes tilstand på følgende måde. »Fame will be great ...for the woman whose reputation for excellence or blame is least known among males«. Kvinderne havde dog deres egne små idrætsbegivenheder. Heriblandt den såkaldte Heraia, til ære for Zeus' kone Hera, der fandt sted på det olympiske stadion umiddelbart før mændene tog fat.

For det tredje afholdes de moderne lege et nyt sted hver gang. I antikken var mødestedet derimod altid det samme

For det fjerde understreger de moderne leges talsmænd, at grundet en arv fra antikken bør de fremme fred og fordragelighed i verden. Da den Internationale Olympiske Komité (IOC), med støtte fra FN, annoncerede en olympisk våbenhvile i dagene omkring vinter-OL i Lillehammer, skete det blandt andet med henvisning til forhold $i$ oldtidens Grækenland. Sammenligningen holder ikke. Grækerne opererede alene med en immunitet, der sikrede, at tilskuere, atleter og trænere kunne drage sikkert til og fra idrætslegene, men mere om dette punkt senere.

Oldtidens grækere ville også have stillet sig totalt uforstående overfor amatørbegrebet, der, i hvert fald indtil for ganske få år siden, var en hjørnesten i den moderne olympiske bevægelse. Ordet athlon betyder på græsk konkurrence og præmie på en og samme tid. Den udbredte opfattelse, at der var amatøratleter på et eller andet tidspunkt i antikken, stammer ikke fra studier af kilder fra den antikke tidsperiode. Antagelsen stammer derimod først og fremmest fra forfattere, der skrev i det sene nittende og tidlige tyvende århundrede, og som ønskede at præsentere den oldgræske tradition som udgangspunkt for deres foretrukne atletiske ideal og sportslige system. ${ }^{1}$

Endnu en forskel mellem antikkens og vore dages lege ligger i holdningen til konkurrenceaspektet. For de gamle grækere gjaldt kun én ting - sejren. Den græske digter Pindar (520-440 f.v.t) beskrev kun vindere i sine olympiske oder, og hvis han 
endelig nævnte en taber, var det kun for at spotte ham. Intet kunne have været mere fjernt fra de oldgræske idealer end det moderne motto. »Det er vigtigere at vare med end at vinde $\ll$.

Blandt de mere kuriøse misforståelser er den, som opstod i forbindelse med tydningen af tekstbrudstykker fundet ved atletikstadion i Delphi. Her mente man, at en inskription bar ordlyden »vin må ikke medtages på stadion «, hvad af moderne olympianere blev udlagt som bevis for, at antikke atleter afstod fra stærke alkoholiske drik$\mathrm{ke}, \mathrm{og}$ at dette måtte tjene som et godt eksempel for nutidige idrætsfolk. Oversættelsen fandt sted i en tid, hvor afholdsforeninger og andre asketisk-puritanske sammenslutninger havde vind i sejlene, hvad selvfølgelig får én til at overveje, om der ikke var tale om en noget lemfældig (var der nogen, der sagde tendentiøs?) anvendelse af informationer fra fortiden til en legitimering og installering af nutidens rette meninger. Under alle omstændigheder har det senere vist sig, at den korrekte oversættelse er »vin må ikke tages med ud af stadion«, hvad unægtelig giver helt andre associationer.

En særlig interessant myte knytter an til de fem olympiske ringe, der flere steder nævnes som et oldgræsk symbol. Det passer ganske simpelt ikke. Symbolet blev opfundet af den moderne olympiske bevægelses fader De Courbetin i 1913. På dette tidspunkt var fem moderne lege afviklet, og De Courbetin skabte derfor et flag med fem ringe, der hver for sig repræsenterede en af de hidtidige værtsnationer, som dermed var fælles om at være fanebærere for olympismens idealer om fred og fordragelighed mellem menneskets slægter. Sandsynligvis var det planen, at der efter hvert afholdt lege skulle tilføjes endnu en ring, således der til sidst var et flag fuldt af ringe symboliserende verdensomspændende olympisk fred og forståelse. Der kom dog et par verdenskrige på tværs, og troen på vedvarende verdensfred blev gemt af vejen. De fem oprindelige ringe fik aldrig videre følgeskab. Grunden til, at de fem ringe alligevel af mange menes at være et oldgræsk symbol, skyldes, at det rent faktisk findes på en stenblok på det antikke stadion ved Delphi. Ringene stammer bare ikke fra antikken, men er derimod

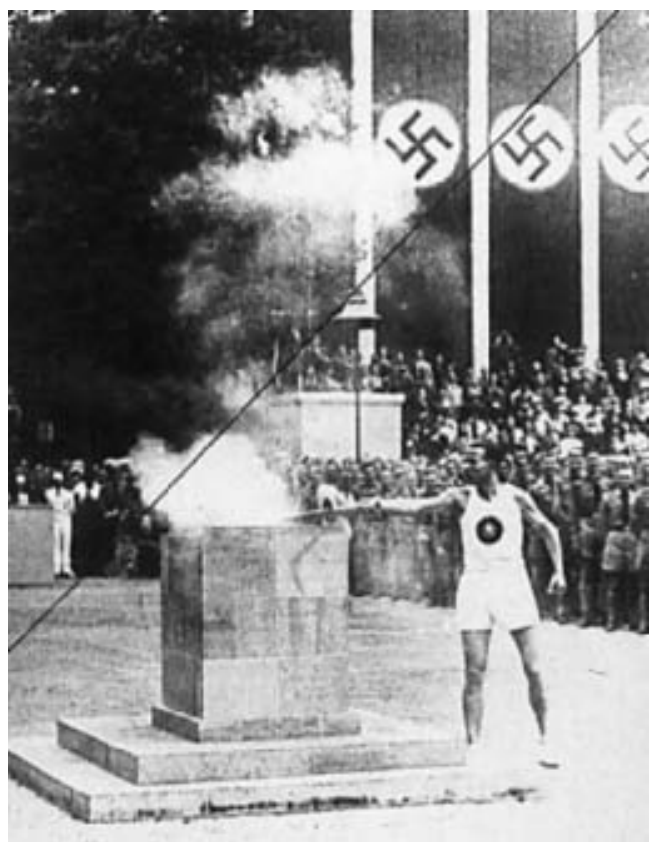

Berlin 1936. En lober tander den olympiske flamme med en fakkel sendt ekspres fra olympia. Det var i forbindelse med Berlin legene, at traditionen med budbringeren og fakkelbareren fra »det gamle grakenlad« tog sin begyndelse. På denne måde søgte Carl Diem, legenes hovedorganisator, at kaste lidt antik aura over begivenheden, der allerede i samtiden var noget slået $u d$ af kurs af de stor-og geopolitiske dønninger, som rorte sig specielt på det europaiske kontinent. 
påført under optagelser til en nazistisk propagandafilm i forbindelse med optakten til legene i Berlin 1936.

Endnu en misforstået sammenblanding af fortid og nutid knytter sig til nazi-legene. Traditionen med at tænde den moderne olympiske ild ved det antikke Olympia, en begivenhed der i dag tv-transmiteres verden over, opstod i forbindelse med Berlin legene, men har absolut ingen sammenhæng med oldgræske traditioner. Den første olympiske fakkel blev fremstillet af Krupp's fabrikker, bedre kendt som våbenleverandør til to verdenskrige.

Den største forskel mellem de antikke og de moderne lege er dog den, at mens de moderne lege er en verdslig begivenhed, var de antikke dybt forankret i religion og religiøsitet. Helt konkret var oldtidens olympiske lege en begivenhed til ære for den mægtigste blandt Olympens guder Zeus. Det religiøse og det sportslige hang altså sammen hos antikkens mennesker, og det er den side af sagen, vi i første omgang vender os mod.

\section{Grask religion og Olympias rolle heri}

»The principle outcome of the four Greek festivals, especially the festival at Olympia, was the observance by all greeks of their already ancient customs, especially the worship of their gods. For more than a thousand years, their delight in highly competitive athletics was inextricably bound to their living religion «. ${ }^{2}$

Dette citat stammer fra en bog skrevet af den amerikanske historiker John A. Lucas, der gennem et langt akademisk liv har haft både de moderne- og antikke olympiske lege som et af sine centrale forskningsmæssige omdrejningspunkter.
Citatet kan tjene som en indgangsbøn til det følgende al den stund, at det bekræfter den indledningvist rejste formodning om, at lege og festivaller (herunder de olympiske) spillede en rolle og tjente et formål i den græske religiøsitet og gudedyrkelse. Førend der sættes focus på denne rolle, vil det dog være givtigt at se lidt nærmere på den religion, der herskede i det antikke Grækenland.

For det første kan det ikke understreges nok, at indholdet i den græske religion var afhængig af og vekslede med den tid og det rum, den eksisterede i. Dette er måske en banal, men ikke desto mindre vigtig pointe.

Vedrørende rum, kan det blot nævnes, at græsk religion helt op til det tidspunkt, hvor den for alvor blev sat under pres af kristendommen, bevarede et islæt af lokal forankring. ${ }^{3}$ Nogle religiøse forestillinger og praksisser var almindeligt udbredte i hele den græske verden, mens andre kun nød anseelse i et yderst afgrænset område. Denne dyrkelse af lokale favoritter var blandt andet mulig, fordi den græske religion var polyteistisk, - altså indebar dyrkelsen af mere end en guddom., 5

Hvad angår tidens indflydelse er det indlysende, at i takt med den græske kulturs udvikling og stadige sofistikering undergik også gudeforestillingerne store forandringer. De oprindeligt mere naive forestillinger om deres virke og fremtræden, hvor ethvert forhold vigtigt for mennesket (høst, jagt, fødsel m.m) blev henført og forbundet med en guddom, blev efterhånden erstattet af en mere nuanceret og kompliceret opfattelse af deres væsen. Denne gradvise omformning er naturlig og uundgåelig. Den græske forfatter Xenophanes konstaterede allerede i det sjette århundrede f.v.t:»mennesket skaber guderne $i$ deres eget billede«. ${ }^{6}$ 
Der skal ikke siges mere om dette punkt, men i stedet forsøge følgende:

For det første; kort ridse nogle af de særkender op, der prægede religionen i henholdsvis den arkaiske og klassiske tidsperiode. For det andet; en yderligere redegørelse for religionens rolle og niveauer i en udvalgt enhed, nemlig den klassiske bystat, på græsk kaldet polis.

\section{Graesk religion i arkaisk og klassisk tid}

I lighed med andre polyteistiske religioner »manglede« den græske en åbenbaring. Den kendte ikke til en profet eller frelser. Den var dybt forankret i en tradition, hvor religionen var tæt sammenknyttet med alle de $\varnothing$ vrige elementer i den græske samfundsorden, der med tiden gav den græske bystat dens form og kendetegn.

Denne religiøse tradition var hverken entydig og ej heller defineret ind i endelige og indiskutable rammer. Den var af natur ikke-dogmatisk, den havde ingen specialuddannet gejstlig stand, den var ikke doktrinær, ganske simpelt fordi den ikke havde en hellig bog som biblen eller koranen, indeholdende de grundlæggende læresætninger. $^{7}$

I arkaisk og klassisk tid var det derfor alt rigeligt at vise sin religiøsitet via deltagelse i en række ritualer, ceremonier, festivaller og ofringer, som jo i og for sig ikke var andet og mere end offentlige handlinger, der blot markerede eksistensen af det guddommelige og en tilsyneladende accept af dette. Religionen blev aldrig hos grækerne en magt, der beherskede hele tankelivet og livsførelsen som hos jøderne eller de kristne. Den manglende interesse i den inderlige og følelsesbetonede tro på guderne er symptomatisk for grækerne. I modsætning til kristendommen havde grækerne ingen »indre agent $«$, der kunne se og straffe de synder, der opstod på det mentale plan og som derfor var usynlige for et andet menneske. ${ }^{8}$ Finley og Pleket opsummerer denne pointe på følgende vis:

»The concern was largely with externals, with rituals rather than beliefs or dogmas. Every community promulgated sacred laws in large numbers, detailed prescriptions defining, for example, who was to sacrifice what, when, and under what conditions, and so on. The individuals inner feelings were his own affair, provided he did not openly blaspheme or deny the existence of the gods «.

\section{Polis religion}

Den græske polis blomstrede op i tidsrummet mellem det ellevte og det ottende århundrede f.v.t. I sin endelige form fremstod polis som en uafhængig enhed, der bestod af to dele - en bykerne og et omkringliggende landbrugsområde. Disse to kunne ikke skilles ad. Etableringen af polis var en konsekvens af en række tekniske, økonomiske og demografiske ændringer, der ialt førte til det den engelske arkæolog Anthony Snodgrass har kaldt »den strukturelle revolution $\ll .{ }^{10}$ Religionen måtte selv sagt tilpasses de nye omstændigheder og undergik derfor store forandringer. For overskuelighedens skyld er argumenterne samlet $\mathrm{i}$ to hovedgrupper.

Den første gruppe af argumenter fremhæver, at religionen fra nu af skulle anvendes som et instrument til at definere størrelsen af den enkelte bystats kulturelle og sociopolitiske rum. Med andre ord blev kultvirksomheden en vigtig bestanddel af den grænse, der markerede linien mellem »os« og »de andre«. Religionen var der- 
med ikke længere kun et privat eller familiemæssigt anliggende, men derimod ligeledes en sag for offentligheden. Religionen blev på godt og ondt institutionaliseret, hvad blandt andet understreges af opførelsen af de mange templer eksempelvis på byernes akropolis. ${ }^{11,} 12$

Blandt andet på baggrund af observationer som de ovenstående, mener den engelske forsker Christiane Sourvinou-Inwood og endvidere andre forfattere som eksempelvis Mckay et al., at religionen var den del af den samlede polis ideologi, som borgerne forventedes at respektere mere end nogen anden. En offentlig demonstration af manglende respekt for religionen var lig med illoyalitet overfor bystaten in toto. Polis, borgernes liv i denne og religionen var tæt forbundet og bekræftede hinanden indbyrdes. ${ }^{13}$

Sourvinou-Inwood går dog videre ved at pointere, den vigtige identitetsskabende og solidaritetsfremmende effekt, der lå i dyrkelsen af polis-religionen:

»The Greek polis articulated religion and was itself articulated by it; religion became the polis' central ideology, structuring and giving meaning to, all the elements that made up the identity of the polis, its past, its physical landscape, the relations between its constituent parts «. ${ }^{14}$

En måde, hvorpå den enkelte bystat kunne markere sin selvstændighed og frihed (centrale værdier for den græske borger), var ved at opbygge en kult omkring en bestemt gud eller en bestemt »udgave « af denne gud. En endnu kraftigere understregning af selvstændighed og individualitet var dog dyrkelsen af hero'er. Hero'erne spillede en vigtig rolle i græsk religion. De tilhørte menneskeslægten og kendte derfor til lidelse og død, men de var samtidig i besiddelse af en række karaktertræk, der adskilte dem fra almindelige dødelige. He- ro'erne havde, ifølge legenderne, levet i en fjern fortid hvor menneskene var højere, stærkere og smukkere, og hvor mennesker og guder stadigvæk færdedes blandt hinanden. Nogle af disse hero'er var kendte i hele det græske område, (nævnes kan Herakles, Achilleus og Theseus) og ofringen til dem kunne tjene mange formål. Langt hovedparten var dog lokale mytiske personer, der kun blev hædret af enkelte landsbyer eller måske af en enkelt bystat. ${ }^{15}$ Dyrkelsen af disse hero'er var indskrænket til nogle enkelte formål, eksempelvis at undgå eller kurere sygdomme eller at ægge de overmenneskelige skabninger til at lade det gå én godt i eksempelvis idrætskonkurrencer eller, hvis det ikke kunne bevilges, gøre livet surt for konkurrenterne. ${ }^{16}{ }^{17}$ Hero'erne befandt sig altså på et slags mellemniveau, der indeholdt elementer fra både den gudelige og den menneskelige verden, men alligevel var noget for sig. Margit Bendtsen et al. drager paralleller mellem hero'erne og de kristne helgener. Selvom man altid skal være varsom med sådanne analogier, mellem fænomener revet ud af den særlige historiske sammenhæng de hver især indgår i, er billedet ikke helt misvisende endda.

Den anden gruppe af argumenter, der inddrages $\mathrm{i}$ forbindelse med diskussionen af udviklingen i den oldgræske religion, gør gældende, at der skulle skabes mulighed for at udtrykke den stigende fornemmelse af (nødvendigt?) fællesskab, der bredte sig imellem de græske bystater. Der var så at sige brug for en religiøs overbygning, som blandt andet skulle opdyrke nogle institutioner, der (både på et mentalt og rent fysisk plan) kunne samle de til dagligt adskilte græske beboere. Løsningen blev opdyrkelsen af de fællesgræske, med et andet ord panhellenske, helligdomme- og lege, hvor Olympia og dets lege kom til at indtage en særstilling. 


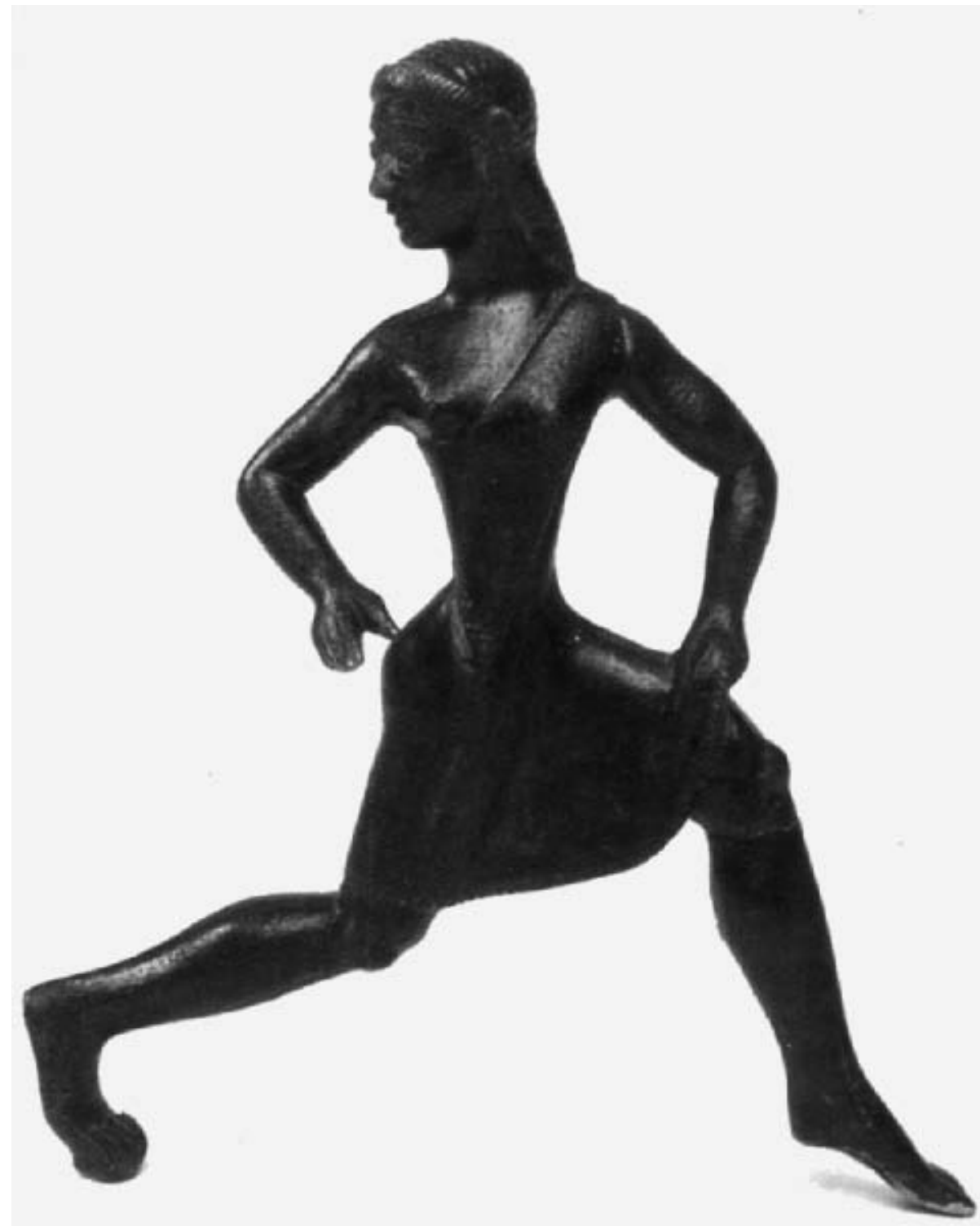

Bronze statue af en kvindelig løber. Bid marke i hendes sarlige chiton, som blotlagger den ene halvdel af brystpartiet. Denne klaededragt anvendtes ligeledes af de graske mand, når det var sarligt varmt. Åbenbart har beklaedningen ligeledes varet $i$ vejen når

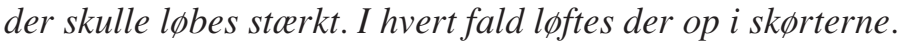

Måske stammer figuren fra Sparta, hvor de unge piger deltog i den omfattende fysiske traning på, om ikke lige fod med, så i hvert fald på pramisser lignende de unge mands.

Pigen, gengivet i figuren, stemmer meget overens med det billede den graske rejsehistoriker Pausanias (143-176 e.v.t) giver os af de piger, som deltog $i$ kvindeløbet ved Olympia, Heraia. "Their hair hangs down, a tunic reaches to a little above the knee, and they bare the right shoulder as far as the breast«.

Tid: cirka 550 f.v.t. 
I sin bog »Athletes and oracles « gør Catherine Morgan opmærksom på en måske indlysende, men dog stadig interessant, detalje vedrørende udviklingen af de panhellenske helligdomme. Selvom (kult)aktiviteten ved disse helligdomme allerede tidligt tog sin begyndelse, så godtg ør arkæologiske fund, at det først var relativt sent, at aktiviteterne blev formaliseret via templer, indstuderede ceremonier og storstilede lege. Således pointerer Morgan, at investering i helligdomme udenfor bygrænsen i det ottende århundrede f.v.t, stadig var noget, der enten påhvilede enkeltpersoner eller prominente familier. ${ }^{18}$ Morgan understreger vigtigheden af, at staten med tiden overtog denne elite's rolle som investor. Dette antyder igen et $\varnothing$ nske fra statens side om at indarbejde individets og familiens interesser i statens.

I det følgende vil der blive peget på et par af de bagvedliggende årsager til den forholdsvise sene udvikling af de panhellenske kultsteder, hvortil hovedparten af græske bystater valfartede.

En forudsætning for at have samkvem med andre stater var selvfølgelig tilstedeværelsen af sådanne. Interessen for et interstatsligt mødested kunne derfor ikke opstå og slå igennem, førend de enkelte stater havde defineret og afgrænset sig selv fra den nære omverdenen, hvilket i første omgang vil sige nabostaterne. ${ }^{19}$

For det andet er det også vigtigt at pege på de panhellenske helligdommes funktion som samlingspunkt for fællesgræskheden. Som både den danske antikhistoriker Aksel Damsgaard-Madsen og Finley og Pleket nævner det, er det ikke tilfældigt, at en begivenhed som de olympiske lege blomstrer op nogenlunde samtidig med kolonitidens begyndelse omkring 700 f.v.t. I forbindelse med kolonisationen kom grækerne i kontakt med nye og fremmedartede skikke og folkeslag. Dette medførte, ifølge Damsgaard-Madsen, en praktisk og åndelig horisont udvidelse. Det frembragte også en erkendelse af et tilhørsforhold til en bestemt gruppering - nemlig den græske - og en trang til at markere dette igennem fælles kultur, religion og religiøse højtideligheder. ${ }^{20}$ Denne sidste kommentar, vedrørende den fælles følelse af græskhed, må dog ikke misforstås. Grækere fra forskellige hjørner af det græske område opfattede ikke sig selv som medlemmer af én (national)stat i moderne forstand. De opfattede først og fremmest sig selv som medlemmer af deres respektive polis. Bystatens grænse var, som nævnt, det, der definerede den første og vigtigste linie mellem én selv og de andre. Det var dog en anden og noget videre grænse, som satte det ultimative skel mellem dem, der et langt stykke hen af vejen var som én selv, og så barbarerne. Det var dette sidste skel, der i første række blev fejret og cementeret ved de panhellenske helligdomme, men den skarpe linie mellem de enkelte bystater blev aldrig udvisket. Dette faktum understreger det tvivlsomme i, hvorvidt erklæringer af fællesgræskhed har haft bærekraft på et niveau, der lå udover det rent retoriske. ${ }^{21}$

I forbindelse med denne artikels belysning af de Olympiske lege's politiske funktion, vil der blive givet adskillige eksempler på enkelte bystater, der udnyttede afholdelsen af en fællesgræsk begivenhed til at understrege eksempelvis magtbalancen i en bestemt region eller slet og ret udstilling af egen formåen.

\section{De religiфse lege}

»The olympic games were founded in 776 B.C. because Olympia was already an established sacred site, not the other way round.$^{22}$ 
Dette citat, lånt fra Finley og Pleket, fastslår, at religionen (og tilstedeværelsen af materialiserede udtryk for denne via helligdomme, altre m.m) var bevæggrunden for overhovedet at etablere idrætslege ved Olympia. Dette må ikke tages som et udtryk for, at al idrætsudøvelse i antikken udsprang af et brændende ønske om at udstille sin loyalitet overfor de olympiske guder. Der kan ikke herske tvivl om, at megen idræt og kropsdyrkelse fandt sin berettigelse i langt mere håndgribelige ting, såsom krigsduelighed og evnen til at forsvare sine egne og sin polis' rettigheder. Et eksempel på grækernes anerkendelse af idrætten som et vigtigt redskab i forberedelserne til krig kan hentes fra en dialog skrevet af den græske forfatter Lukian fra Samosta (120180 e.v.t). I denne dialog lader Lukian lovgiveren Solon (640-560 f.v.t) belære skytheren Anarcharsis om, hvilke funktioner idrætten og kropsdyrkelsen havde. Efter at Solon har gennemgået de mange discipliner, der blev dyrket i det dertil indrettede Gymnasion, opsummerer han på følgende vis.

„Dette, Anarcharsis, er de Øvelser, vi lader de Unge hos os gennemgaa, fordi vi tror, at de saa vil blive os gode Vogtere af Staten og skaffe os Mulighed for at leve $i$ Fred, idet vi dels kan faa Bugt med vore Fjender, hvis de skulde angribe os, dels er skrakindjagende for vore Naboer, saa at de baade ydmyger sig for os og for storste Delen betaler os Tribut «. ${ }^{23}$

Finley og Pleket peger på, at den ovennævnte symbiose mellem krig og idræt stædigt blev holdt i hævd på trods af både professionalisering af hæren og ændringen af statsstrukturerne i 300-tallet f.v.t, hvor de små bystater blev underlagt de hellenistiske kongeriger, ${ }^{24}$ og dermed mistede behovet for egne soldater. Atleter og poeter fortsatte med at sætte lighedstegn mellem den olym- piske vinder og den tapre kriger. En forklaring på denne standhaftighed er muligvis, at selvom deltagelse i direkte krigshandlinger med tiden blev en realistisk mulighed for stadig færre, så vedblev krig og strid dog med at være en yderst nærværende og synlig faktor i oldgrækernes liv.

Endvidere har den markante konkurrencementalitet, der herskede $i$ alle sfærer af det græske samfund, og som kom stærkest til udtryk via det homeriske motto, at man altid bør vare bedst, været med til at fremme en institution, som eksempelvis De Olympiske Lege. ${ }^{25}$ Når dette er sagt står dog tilbage, at religion og idræt, ligeså langt tilbage vi kan spore de to fænomener i den græske historie, har været tæt forbundet. De Olympiske Lege var altså ingen undtagelse.

Alle lege og festivaller var bygget op omkring den samme kerne af elementer; Tilbedelse, processioner, ofringer og bønner. Udover dette var der så fest/banket og konkurrencer i musik, dans, drama, lyrik og sport. Olympia's ensidige koncentration omkring atletik var enestående.

De Olympiske Lege var endelig færdigorganiseret og udformet tidligt i det femte århunderede f.v.t. På dette tidspunkt var legenes varighed fem dage, heraf optog religiøse ceremonier m.m en ikke ringe del. ${ }^{26}$

\section{Ekskurs}

Det kan her være givtigt at gøre et mindre ophold, for at knytte nogle kommentarer til den udtalte uenighed, der hersker om, hvor mange dage af det olympiske program, der var forbeholdt religiøse seancer. Finley og Pleket mener, at både første-, tredje- og femtedagen var præget af kultiske handlinger, og at klimakset allerede lå på førstedagen i forbindelse med ofringen af 100 okser til ære for Zeus. Modsatvis påstår amerikaneren David Matz, at kun første- og 
sidstedagen indeholdt religiøse elementer. For at gøre forvirringen total kan afslutningsvis refereres til Margit Bendtsen et al., der, i overensstemmelse med Finley og Pleket, mener at tre af legenes ialt fem dage havde religionen i højsædet. Til gengæld placerer Bendtsen et al. det store offer til Zeus, der var legenes absolutte $h ø j-$ depunkt, på tredjedagen og endvidere $g ø r$ forfatterne gældende, at antallet af okser, der blev ofret, ikke kan fastslås med sikkerhed, men at det dog er sikkert, at Elæerne (de olympiske værter) stod for hovedparten, -nemlig en hel hekatombe (dvs. 100) okser.

Ekskurs slut

Hvor om alting er; ofringen var, som nævnt, en central del af al græsk religion. Dette skyldes, at selvom de græske guder var udødelige og overmenneskelige, så havde de absolut deres humane sider; de drak, spiste, elskede, skændtes og nød luksus. En måde, hvorpå det enkelte individ eller en gruppe kunne ære og efterligne guderne, var derfor ved at dele det afkast, man opnåede enten via høst, håndværk eller krigsførelse med dem. ${ }^{27}$ Ofringen af okser på Zeus' alter i Olympias hellige centrum - Altis - kan altså ses som en handling, hvorved mennesket kunne komme tættere på guderne.

Men netop den noget blodige affære med Zeus og okserne kan også tjene som eksempel på et andet centralt element $\mathrm{i}$ græsk religion og tankegang. Ligesom idræt og krig var nært beslægtede i den antikke virkelighed, var døden og livet komplementære temaer i græsk religion, kult og myte. ${ }^{28}$ Religionshistorikeren Walter Burkert, der blandt andet har skrevet det omfattende værk »Greek Religion«, mener, at offerdrabet var det helt afgørende træk ved græsk religion.
»Ikke i den fromme livsvandel, ikke i bønn, sang og dans alene blir guden opplevd på det megtigste, men snarere $i$ det dødelige $\phi k s e h u g g$, blodet som renner ut og $i$ forbrenningen av kjøttstykkerne. ... Homo religiosus handler og blir seg selv bevisst som Homo Necans ${ }^{29}$

Homo Necans »det dræbende menneske« er ligeledes titlen på en anden bog skrevet af Burkert. Heri godtgør han, at den oldgræske religion havde sit første udspring i den præhistoriske jagt. Religionen skal ses som den rituelle manifestation og videreførelse af denne jagt, og mennesket kan på denne vis få tilfredsstillet et behov for drab og vold gennem symbolske og billedlige handlinger.

Denne tvedelte opgave, som ofringen til Zeus havde i Olympia, genfindes også i forbindelse med andre guder. Ofre som korn og vin symboliserer og aktualiserer guder som; Demeter og Dionysos (selvom Dionysos jo ikke altid er at finde i det fine selskab på Olympen). Disse to guder er knyttet til vegetationen, og på denne vis bliver de i en videre forstand knyttet til jordens årscyklus, der jo er en evig re- og degenerering af livet. Død er en forudsætning for liv. Dette var et faktum som grækerne, i ret så håndfast form, havde tæt inde på sig hver eneste dag, og det er derfor ikke underligt, at de mindede sig selv og andre om dette via religiøse ceremonier og ofre.

\section{Afrunding}

De ovenstående sider har forhåbentlig givet et første indblik i den religiøsitet, der herskede i den græske oldtid, og endvidere hvilke funktioner en interstatslig institution som Olympia havde i denne. En religiøsitet, som den græske, var for det første præget af mange myter, kulter og flerguderi, men dernæst tjente den også det formål 
at opstille en forståelses- og forklaringsramme for den enkelte, der således kunne styrke fornemmelsen af sammenhæng og mening med livet. Dette sidste formål er i $\varnothing$ vrigt centralt for alle religioner og trosfællesskaber. Den amerikanske sociolog Robert Merton har, blandt andet via sine studier af Hopi-indianernes naturreligion, givet mange gode eksempler om dette aspekt. Hopi'ernes religion indeholder mange ceremonier og ritualer, der, på et abstrakt og for den enkelte ofte skjult (hos Merton latent) niveau, virker positivt i retning af sammenhold og integration i indianersamfundet.

Det er endvidere blevet foreslået, at religionen, på et mere samfundsmæssigt plan, var et vigtigt, måske det vigtigste middel $\mathrm{i}$ bestræbelserne på at skabe en opmærksomhed omkring et fællesskab med nogen, det være sig på landsby-, polis- og/eller fællesgræsk niveau og en anderledeshed i forhold til andre. Religionen var, i stil med hvad sexualiteten eller sundheden er i dag, den mindste fællesnævner - lingua franca - og som sådan skabte den en fælles mening- og referenceramme. ${ }^{30}$

Tilbage er nu kun at besvare spørgsmålet, hvorfor religionen tit og ofte udtrykte sig igennem eller optrådte sammen med idrætten.

Mange forfattere giver deres bud på ovenstående spørgsmål, men alle dækker de sig ind bag forskellige former for forbehold. Dette skyldes blandt andet, at det er uhyre vanskeligt at kortlægge de primære årsager til idrættens/atletikkens opståen.

I bestræbelserne på at finde kilden til idrætten har nogle peget på menneskets, og specielt barnets, naturlige lyst til leg og fysisk bevægelse, og i forlængelse af denne argumentation har andre understreget den respekt, der i tidligere samfund stod omkring fysisk kraft og kunnen, der jo var grundlaget for overlevelse via jagt og kamp. ${ }^{31}$

Sammenhængen mellem krig og idræt har allerede været berørt, men det er nok tvivlsomt, om idræt ene og alene er opstået grundet et militært behov for træning af soldater.

Denne artikels rammer levner dog ikke plads til en fordybelse i idrættens genesis, og denne problemstilling må derfor vige pladsen for det primære, nemlig en forklaring på idrættens forhold til religionen og vice versa.

Nogle forfattere har begrænset sig til at pege på, at idrætten tjente et underholdningsformål $\mathrm{i}$ forbindelse med religiøse samlinger som dem ved Olympia. Dette synes at være en noget overfladisk forklaring, der ikke efterlader idrætten, og idrætsudøveren, med stort andet end rollen som pauseklovn. Taget i betragtning hvor megen vægt grækerne lagde på fysisk aktivitet, hvad blandt andet kan godtgøres ved at pege på den vigtighed, man i bystaterne lagde på opførelsen af gymnasier, ${ }^{32}$ eller ved at minde om den græske kunst som $\mathrm{i}$ næsten et årtusinde lod sig inspirere af motiver fra idrættens verden (med en diskret, men umiskendelig homofil interesse), er det vanskeligt at forestille sig, at de udelukkende så idrætten som en adspredelsesmulighed..$^{33}$ Denne slutning har gyldighed, både når der focuseres på idrætstilskuerne, men så sandelig også når det gælder idrætsudøverne, der uden tvivl tog deres deltagelse (død)alvorligt.

En langt mere fascinerende, men samtidig også rimelig, forklaring på samspillet mellem religionen og idrætten, er, at deltagerne og tilskuerne gennem de agonistiske konkurrencer artikulerede deres tiltro til guderne og symbolsk udspillede kampene imellem dem.

I forbindelse med disse lege kan det 
forestilles, at brydekampene blev opfattet som en reaktualisering af Zeus' kamp og sejr over sin fader Kronos, mens boksningen og løbet havde forbindelse til Apollons sejre over henholdsvis Hermes og Ares. ${ }^{34}$

Hero'erne blev heller ikke glemt. Eksempelvis blev Pelops' sejr over Oinomaos mindet via hestevæddel $\varnothing$ bene på hippodromen og Herakles (antikkens supermand og måske af os bedre kendt som romernes Herkules) blev af grækerne selv opfattet som grundlæggeren af al idræt. Iøvrigt fortalte myten, at det var Herakles, der i tidernes morgen havde fastsat den olympiske løbebanes længde til 600 fod. De 600 fod var netop lig med den længdeenhed, som grækerne benævinte en stadion. ${ }^{35}$

Den tanke strejfer også én, at de deltagende atleter identificerede sig med guder og hero'er, og det er også muligt, at tilskuere så guderne spejle sig i atleten. I dialogen mellem Solon og Anarcharsis kan der findes næring til en sådan formodning

»Vaddekamperne bliver lovpriste, og sarlig den af dem, der har vundet Sejr, agtes lige med en Gud «. ${ }^{36}$

I alle tilfælde er der ingen tvivl om, at et folkefærd som det græske, med deres yderst menneskelignende guder, har haft den forestilling, at disse ville finde behag $\mathrm{i}$ atletiske lege.

Selvfølgelig er gyldigheden af denne konklusion afhængig af, hvilken tid der hentydes til.

For det første kan der ikke rejses tvivl $\mathrm{om}$, at religionen efterhånden mistede sin status som det altoverskyggende formål med De Olympiske Lege. Denne udvikling kan blandt andet illustreres ved, at mens det ældre olympiske stadion lå halvvejs inde i selve det hellige område ved Olympia, blev det yngre totalt adskilt herfra. ${ }^{37}$

For det andet er det værd at bemærke, at professionalisme, altså deltagelse med det formål for øje at tjene en gevinst derpå, til alle tider havde været en del af legene.

De Olympiske Lege og »auraen« omkring disse blev dog også brugt politisk, og det er dette aspekt vi nu vender os mod.

\section{De Olympiske Leges politiske funktioner}

Det er på sin plads, indledningsvist, at strejfe spørgsmålet hvorfor de antikke grækere udvalgte netop Olympia til deres foretrukne religiøse- og politiske panhellenske mødested.

For det første kan der peges på et forhold, der allerede har været nævnt, nemlig De Olympiske Lege's alder, som placerede dem i en klasse for sig (de tre vigtigste atletiske lege udover de olympiske - de pythiske, de nemæiske og de isthmiske opstod i det sjette og det femte århundrede f.v.t). ${ }^{38}$

For det andet peger Margit Bendtsen et al. på en yderst praktisk bevæggrund. Som det måske erindres, opstod og udvikledes De Olympiske Lege i koloniseringsperioden, og afholdensen af dem var således en velkommen mulighed for kolonisterne til at mødes under fredelige forhold i hovedlandet. Olympia's geografiske placering gjorde det til det naturlige valg for en sådan samling fremfor eksempelvis Delphi. ${ }^{39}$

For det tredje gør Finley og Pleket opmærksom på en vigtig detalje vedrørende det rejste spørgsmål. På grund af og ikke på trods af, at Olympia aldrig udviklede sig til et ordnet samfund endsige en regulær bystat, men til alle tider forblev et udelukkende religiøst område, og endvidere på grund af at Elæerne, der fra cirka 570 f.v.t kontrollerede området omkring Olympia, og derfor ligeledes havde det prestigefyldte hverv at afvikle legene, aldrig blev 
en politisk- og militær magt af betydning, kunne De Olympiske Lege undergå forvandlingen fra lokalt kultsted til panhellensk helligdom. ${ }^{40}$

„Games everywhere were managed by local authorities, not by an international committee, and the weaker that authority the less the risk that the prestige of a great festival would enhance its political power. Athletes from all over the Greek world could safely compete for their own glory and that of their own cities, without building up the prestige of a powerful hostcommunity ${ }^{4}{ }^{41}$

\section{Den Olympiske fred}

Den hellige fred var en særegen olympisk praksis, der virkede $\mathrm{i}$ en afgrænset periode før, under og efter selve legene. Præcist hvor lang tid freden var i kraft er vanskeligt at svare på, men Finley og Pleket finder det sandsynligt, at freden i første omgang var af en måneds varighed på hver side af legene, og at den med tiden blev udvidet med måske helt op til tre måneder, efterhånden som atleter og tilskuere kom fra stadig fjernere beliggende områder, som eksempelvis de talrige kolonier grundlagt af bystater på hovedlandet.

Årsagen til fredens benævnelse som hellig er indlysende den, at alt hvad der blev forbundet med Olympia - pr. definition var under Zeus' beskyttelse. Freden havde altså i første omgang sit udspring i religiøsiteten, men det er klart, at den også havde politiske konsekvenser. Freden satte aldrig en stopper for konflikter eller krige, hvad ingen heller gjorde sig forestillinger om. ${ }^{42}$ I hele den Olympiske tidsalder var krige uundgåelige og selvfølgelige. Disse krige kom i alle afskygninger og størrelser. Lige fra småslagsmål om grænsen mellem to bystater til de lange og opslidende krige i sidste tredjedel af det femte århundrede f.v.t mellem Athen og Sparta. Senere - i hellenismen - sloges monarkerne, og til sidst fandt også de romerske borgerkrige vej til den østlige del af den græske region. Forløbet i disse konflikter havde den hellige fred i forbindelse med De Olympiske Lege ingen (direkte) indflydelse på overhovedet, men det var heller ikke på noget tidspunkt meningen. Formålet med den olympiske fred var, ganske simpelt, at muliggøre afviklingen af legene på trods af de talrige krige. ${ }^{43}$ Fredens statutter, om man vil, var indgraveret på en bronzetavle, opbevaret i Hera-templet i Olympia. Heraf fremgik, at alle stater, der ønskede at deltage i De Olympiske Lege, måtte afholde sig fra våbenbrug, forfølgelse og dødsstraf så længe freden varede. ${ }^{44}$ I følge Finley og Pleket tyder meget på, at de græske bystater rent faktisk var endog meget påpasselige med at overholde de udlagte regler. Som svar på det uundgåelige »hvorfor «, kan gives følgende. For det første blev de, der ikke var i stand til eller ikke ønskede at (over)holde freden, idømt en, som oftest, $\varnothing$ konomisk straf. For det andet var freden hellig og forbundet med den mægtigste blandt guderne - Zeus - og det var de færreste, der havde lyst til at sætte sig op mod en sådan kraft. For det tredje var deltagelse i De Olympiske Lege et så vigtigt anliggende for de græske bystater, at de meget nødig ville risikere udelukkelse. ${ }^{45}$

Den hellige fred var altså i stand til at skabe ro i Olympia, sålænge legene varede og ligeledes garantere de tilrejsendes sikkerhed. Indenfor en bred definition af begrebet politik og politiske handlinger og tiltag, kan man derfor sige, at den hellige fred indeholdt politiske aspekter, men i samme åndedrag må det erkendes, at disse var af indirekte og ikke særlig håndgribelig 
karakter og forøvrigt tjente et utroligt snævert formål. Det er følgeligt umuligt at vurdere, hvor stor politisk gennemslagskraft denne erklærede fred havde på mere generelle politiske forhold i antikken. Fristende er det derfor at spørge, om det ikke ville være naturligt, at der i forbindelse med en fællesgræsk festival, varende i fem fulde dage, blev diskuteret mere konkrete stridsspørgsmål bystaterne imellem, og endvidere om dog ikke enkelte polis'er eller enkeltpersoner greb den enestående chance for P.R.-arbejde.

Adskillige forskere har fors $\emptyset \mathrm{gt}$ at besvare ovenstående spørgsmål og er kommet frem til forskellige muligheder. Finley og Pleket lægger ud med at erklære sig enige $\mathrm{i}$, at det ville have været fornuftigt for de græske bystater at diskutere »udenrigs «politik og samarbejde på tværs af grænser, når de nu alligevel var samlet. De to forfattere mener dog at kunne konstatere, at grækerne sjældent benyttede sig af denne mulighed, og de forfølger derfor ikke hypotesen videre. I stedet gør de opmærksom på det frugtbare i at focusere på spørgsmålet; hvilke »indenrigs«politiske fordele en eventuel olympisk sejr kunne indebære. ${ }^{46}$ Andre forskere, som eksempelvis de engelske arkæologer Anthony Snodgrass og Catherine Morgan, deler ikke Finley's og Pleket's synspunkt. De er overbeviste om, at de panhellenske helligdomme var rammen om såvel politisk som sociokulturel samkvem mellem bystater. Årsagen til den noget forskellige udlægning hos de nævnte forfattere skyldes, at Finley og Pleket, i forhold til de to øvrige, arbejder med et langt snævrere syn på, hvad der hidrører det politiske, og hvad der falder udenfor.

På de følgende sider vil vi først se på, hvorledes De Olympiske Lege kunne have afgørende indflydelse på forhold internt $\mathrm{i}$ en enkelt polis, nemlig Athen. Denne redegørelse vil bygge på en mere generel diskussion af sammenhænge mellem idræt og politik i tiden frem til hellenismens spæde begyndelse omkring Philip D.II og Alexander den stores togter.

Derefter vil Olympia's rolle som fællesgræsk knudepunkt kort blive beskrevet.

\section{De Olympiske Leges indflydelse på interne politiske forhold $i$ Athen}

Agonisme, denne yderst græske interesse $\mathrm{i}$ at konkurrere og være den fremmeste blandt ligemænd, var en endog meget aktiv medspiller i såvel antikkens idræt som politik. Det motiv, der lå bag denne trang til kamp var philotomia, ønsket om at opnå anerkendelse for sin personlighed og i særdeleshed sine handlinger. Således ræssonerer i hvert fald den amerikanske historiker Donald G. Kyle i sin bog »Athletics In Ancient Athens«, der er at regne som et hovedværk om idræt $\mathrm{i}$ antikken. ${ }^{47}$

Kyle mener for det første at kunne observere en forandringsproces $\mathrm{i}$ forholdet mellem politik og idræt i Athen, som tidsmæsigt kan inddeles $i$ tre forholdsvist præcist afgrænsede faser. For det andet fremgår det af Kyle's arbejde, at en tilsvarende udviklingsproces finder sted i forbindelse med De Olympiske Leges indflydelse på athensk »indenrigs«politik.

\section{Fase 1: Med kroppen på spil $i$ både idraet og politik}

Denne periode strækker sig fra det ottende århundrede f.v.t til og med et sted i det sjette. I denne periode var der en tydelig sammenhæng mellem på den ene side person- 
lig atletisk præstation og deraf følgende berømmelse og på den anden side stræben efter politisk indflydelse og magt. Athen var endnu blot på vej mod de samfundsmæssige omvæltninger, som lagde grunden til den klassiske polis og borgermentaliteten. Langt op i Arkaisk tid var det stadig adelens »gamle « familier og deres idealer, der herskede, og det var ligeledes dem, som udgjorde Athens politiske og atletiske kerne. Hvad enten det var på hippodromen, på stadion eller den politiske scene kunne man være sikker på, at aktørerne tilhørte det aristokrati, der grundet familie- og tradionsmæssige forhold var herskende.$^{48}$ Der er mange eksempler på familier, som i generation efter generation fremhævede sig både politisk og idrætsligt. Her skal der dog kun gives et enkelt, der så til gengæld er et af de mest tydelige og almindeligt kendte. Det omhandler den herostratisk berømte tyrantaspirant Kylon, der ifølge Thukydid var ud af en fornem og indflydelsesrig familie. ${ }^{49}$ Kylon vandt i 640 f.v.t diaulos (400-meter) løbet ved de Olympiske lege og brugte denne begivenhed til at træde ind i politik. Et orakelsvar fra Delphi havde kundgjort, at han og hans følge skulle indtage den athenske akropolis i forbindelse med den største fest i Zeus' navn. Kylon var overbevist om, at der blev henvist til De Olympiske Lege, en opfattelse der selvfølgelig blev understøttet af hans egen status som olympisk sejrherre. Han forsøgte derfor et kup, som dog mislykkedes fuldstændigt, blandt andet på grund af de Attiske bønders manglende støtte. ${ }^{50} \mathrm{Mu}$ ligvis havde Kylon håbet, at hans olympiske meritter ville betyde bred opbakning bag hans foretagende, men måske indskrænkede denne opbakning sig til folk fra hans eget sociale lag - aristokratiet.

Under alle omstændigheder illustrerer ovenstående eksempel, at idrætspræstatio- ner på Kylon's tid blev henregnet som et potentielt aktivt politisk våben.

I slutningen af denne første periode gennemførte statslederen Solon i Athen en række politiske og $\varnothing$ konomiske reformer, der kom til at stå som det første store skridt imod det klassiske direkte demokrati, samt som den skelsættende begivenhed der for alvor illustrerede slægtens vigende indflydelse til fordel for borgerfællesskabet. ${ }^{51}$ Donald G. Kyle mener endvidere, at Solon udover dette sørgede for, at områder, som hidtil havde været private domæner for den føromtalte elite, blev indlemmet i statens affærer, og fremhævet som noget der burde have alle borgeres interesse, uanset formue og status. Kyle og andre forfattere sandsynligg ør, at det var Solon, der indførte en forordning, som belønnede vindere i atletiske lege med en statslig pengegave, og dermed anerkendte atleten som en person, der tjente hele samfundet og ikke bare sig selv. Den omtalte pengegave var af et ikke ringe omfang: 500 Drachme for olympisk sejr og 100 Drachme for en isthmisk, hvad svarede til et par årsindtægter for en almindelig håndværker. Afslutningsvis skal det dog understreges, at selvom Solon var den første, der fors $\varnothing$ gte at anvende idrætten politisk i statens tjeneste, så vedblev sammensmeltningen af atletisk- og politisk lederskab i det meste af det sjette århundrede f.v.t med at være et realistisk foretagende for få udvalgte grupper. ${ }^{52}$

\section{Fase 2: Idrat for sig og politik for sig - en professionel arbejdsdeling finder sted}

Denne fase indeholder slutningen af det sjette århundrede f.v.t og tiden frem til de peloponnesiske krige's ophør i 404 f.v.t. 


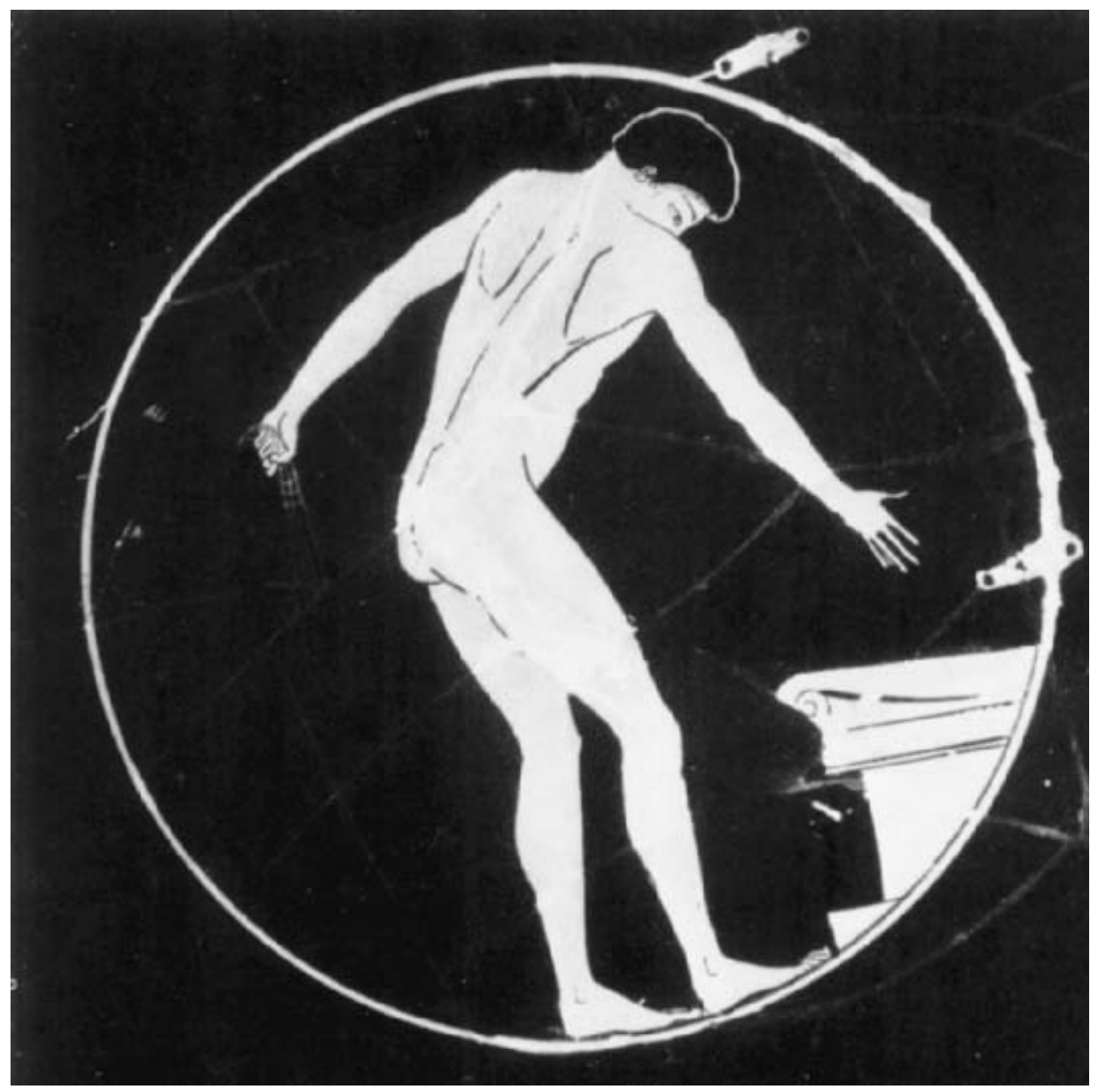

En ung noevekcemper holder $i$ den ene hånd sine himantes, kamp remedier. Den anden hånd er udstrakt pegende mod et alter. Hermed understreges den storke sammenhaeng mellem fysisk kunnen og den religiфse dimension i den antikke verden.

Mon det er en af de olympiske guder, som ares. Eller er det måske den lokale hero, som bedes komme ynglingen til hjoelp i kampens hede?

Billedet stammer fra en drikkekop.

Tid: $500-475$ f.v.t.

Tidsperioden var rammen om store forandringer indenfor både politik og idræt, og forholdet mellem de to blev derfor ligeledes af en anden karakter. Focuseres der først på det politiske aspekt, kan reformerne gennemført af statslederen Kleisthenes (500-tallet f.v.t) og perserkrigene fremhæves som nogle af de faktorer, der henholdsvis skubbede og sikrede Athen's videre udvikling i demokratisk og imperialistisk retning. Kleisthenes skubbede på med de politiske reformer, han fik gennemført i 
overgangsårene mellem det sjette- og det femte århundrede f.v.t, der betød en ophævelse af den gamle samfundsorden byggende på slægterne og en indførelse af lokal administrativ ledelse. Dette gav det athenske forfatningssystem den grundstruktur, som det i grove træk bevarede i hele den klassiske tid. ${ }^{53}$ Hvilken betydning det havde for udbyggelsen af det græske demokrati, at grækerne og ikke perserne vandt den indbyrdes krig er et spørgsmål, der altid vil være en kilde til diskussion. Sådan er det med spørgsmål af kontrafaktisk karakter. Damsgaard-Madsen er dog sikkert på fast grund, når han konstaterer; at en græsk region i form af en persisk provins, ikke ville have haft plads til et dynamisk og altomfattende demokrati med personligheder som Perikles (492-429 f.v.t), Demosthenes (383-322 f.v.t politiker, sagfører og en af oldtidens betydeligste talere) eller Sokrates (469-399 f.v.t).

Hvad angår idrættens verden kan det fremhæves, at den oplevede vigtige omvæltninger, der forløb sidel øbende med de politiske. For det første $\emptyset$ gedes antallet af udøvere, men ifølge Kyle må dette ikke tages som et udtryk for, at idrætdyrkelse var blevet en folkelig foreteelse i egentlig forstand. Atleterne skulle vedvarende søges i de høje sociale lag, men til forskel fra tidligere var det ikke længere aristokraterne med deres fødselsbestemte rettigheder, der dominerede, men derimod personer fra familier som Kyle benævner de ny-rige (neoploutoi) ${ }^{54}$ Idræt var altså stadig for eliten, men denne var i højere grad bestemt via $\varnothing$ konomiske midler end ved en uds $\varnothing$ gt- og traditionsrig herkomst. For det andet fremhæver Kyle, at disse nye atleter lagde mere vægt på forberedelse og træning i stedet for naturlige evner og kunnen, hvad synes naturligt, i og med mange af de ny-rige atleter kom fra familier, der i højere grad havde arbejdet og ikke arvet sig til social position og politisk indflydelse.

Den skitserede udvikling indenfor såvel det politiske som det idrætslige betød, at begge blev områder, hvori der kun kunne forventes succes, såfremt man udelukkende koncentrerede sig om det ene. I lighed med de nye idrætslige idealer satte også demokratiet focus på tilegnede egenskaber såsom veltalenhed og indsigt $\mathrm{i}$ statens interesser. Midlerne til at opnå og bevare magt var ikke længere en simpel påmindelse om arv og traditioner. De var langt mere komplicerede og krævede derfor ledernes fulde opmærksomhed og talent. ${ }^{55}$

Aktiv og direkte deltagelse på topplan i både idræt og politik blev således et stadig mere sjældent fænomen. ${ }^{56}$ I stedet for anvendte diverse athenere idrætten og konkurrencer heri som led i deres politiske P.R.-arbejde. Dette skete enten ved at optræde som sponsor eller administrator af idræt. En anden mulighed, der dog efterhånden blev et sjældent syn, var deltagelse i hestevæddel $ø$, for på den måde at opnå offentlig omtale og prestige. At deltage i idrætslege via hestevæddel $\varnothing$ bene krævede ikke en lang og anstrengende træningsperiode, men derimod blot pengene til at købe heste og hyre en kusk. En efterfølgende sejr ville være ligeså anvendelig i politisk og andre henseender, som en sejr i eksempelvis brydning, fordi sejren, ligesom i vore dage, blev tilskrevet hestenes ejer. ${ }^{57}$

En historisk person, der med (i hvert fald indledningsvist) held anvendte hestevæddeløbsmetoden, var aristokratsønnen og folkelederen (nogle ville sige folkeforføreren) Alkibiades (450-404 f.v.t).

Alkibiades brugte sine olympiske sejre til at overbevise den athenske folkeforsamling om, at han var den rette til at lede den flåde, der i 415 f.v.t skulle undsætte athenernes allierede på Sicilien. Alkibiades 
blev dog under toget tilbagekaldt til Athen grundet mistanken om hans deltagelse $\mathrm{i}$ den såkaldte Herme-skandale, hvor en række hellige støtter var blevet skamferet. Alkibiades undslap til Sparta og vendte i triumf tilbage til Athen i 411 f.v.t, men lykken vendte igen og han blev myrdet få år senere. ${ }^{58}$

Uden at overraske kan det nævnes, at Alkibiades blev det seneste eksempel, der er bevaret om en sådan sammenblanding af (indirekte) deltagelse i idrætskonkurrencer og politik. Sporene og den folkelige hukommelse skræmte åbenbart.

\section{Fase 3: Magtpolitisk nedtur- sportslig, kulturel og фkonomisk blomstring}

Tidsmæssigt befinder vi os nu i det fjerde århundrede f.v.t. Athen havde tabt den afgørende fase i de peloponnesiske krige (431-21 og 413-04 f.v.t) og blev derfor tvunget til indgåelsen af en fredsaftale, der i nogen udstrækning stækkede dens handlekraft som selvstændig bystat. Befæstningerne mellem den naturlige havn Piræus og selve byen skulle rives ned, resterne af den førhen så strålende flåde skulle udleveres, og alle besiddelser udenfor Attika skulle afstås på nær nogle få øer. Udenrigspolitisk måtte Athen indordne sig under Sparta. Athen forsvandt dog ikke fuldstændig ud af græsk storpolitik i det fjerde århundrede, men det var andre stater, såsom Sparta, Theben og frem for alt Makedonien, der på skift havde den altafgørende indflydelse i den græske region. ${ }^{59}$ Indenrigspolitisk fik athenerne lov til at videreføre demokratiet og efter et forsøg på indførelse af fåmandsvælde (oligarki) havde slået fejl, fortsatte de demokratiske organer derfor med at fungere helt op til og ind i hellenismen, der jo som nævnt tidligere blev præget af de primært Makedonsk kontrollerede konged $\varnothing$ mmer.

I løbet af denne tredje fase ophørte ethvert sammenfald mellem idræt og politik. $^{60}$

Det var der flere grunde til.

For det første fortsatte specialiseringen og institutionaliseringen af såvel det politiske som det idrætslige liv, og en aktiv deltagelse i begge sfærer var umulig. Den generelle udvikling indenfor mange områder i det fjerde århundrede f.v.t betød, at de hver for sig krævede deres mand fuldt og helt. Eksperter med indsigt var påkrævet indenfor militær, фkonomi o.s.v. ${ }^{61}$ Dette faktum kan tænkes at have fjernet den sidste rest af overførselsværdi, der måtte have været tilbage mellem atletisk succes og politisk indflydelse. Hvorfor vælge en suveræn atlet til et politisk embede, som man udmærket vidste, han ikke havde evner og ej heller uddannelse til at bestride.

For det andet gør Kyle gældende; at det fjerde århundrede f.v.t, der fulgte umiddelbart efter de peloponnesiske krige, var præget en svækkelse af den følelse af borgerfællesskab, der havde været en bærende bestanddel i det levende Athenske politiske liv. Den gamle jordejende adel havde definitivt trukket sig tilbage fra den politiske scene, og »en anden slags mennesker« overtog ledelsen. Kyle mener, at den politiske mentalitet og borgernes patriotisme, som tilsammen havde sikret en følelse af forpligtigelse overfor en bevarelse af bystaten, blev erstattet af en $\varnothing$ konomisk og selvcentreret klassebevidsthed, der fremhævede individets ret til at tjene sig selv mere og samfundet mindre. ${ }^{62}$ Med overvejelser, som de nævnte, nærmer Kyle sig en af de kæpheste, mange forfattere og forskere har knyttet sig til i forbindelse med deres beskrivelse af Athen i tiden efter Perikles og i 
Stregtegningen, der stammer fra Italien, er antagelig fra de sidste årtier af 1400-tallet og gengiver brydekampen mellem den antikke superhelt Herakles og giganten Ataios. Billedet er et typisk eksempel på såvel rennoessancekunstens stil og mest yndede motiv (mennesket $i$ centrum) som samme periodes intense interesse for grask-romersk historie, kunst og kultur.

I folge den graske mytologi var Ataios en uovervindelig slagsbroder, som drabte alle sine modstandere. Herakles fandt dog ud af, at Ataios styrke lå gemt $i$ hans stadige kontakt med jorden, som var hans mor. Herakles løftede derpå sin modstander fri fra moder jord og kvalte ham.

Herakles var, ifølge oldtidens vandrehistorier, iфvrigt en stridslysten og virksom herre. Kampen med Ataios lå eksempelvis udover de velkendte tolv opgaver Herakles skulle udføre som bod for en forbrydelse hans far havde begået.

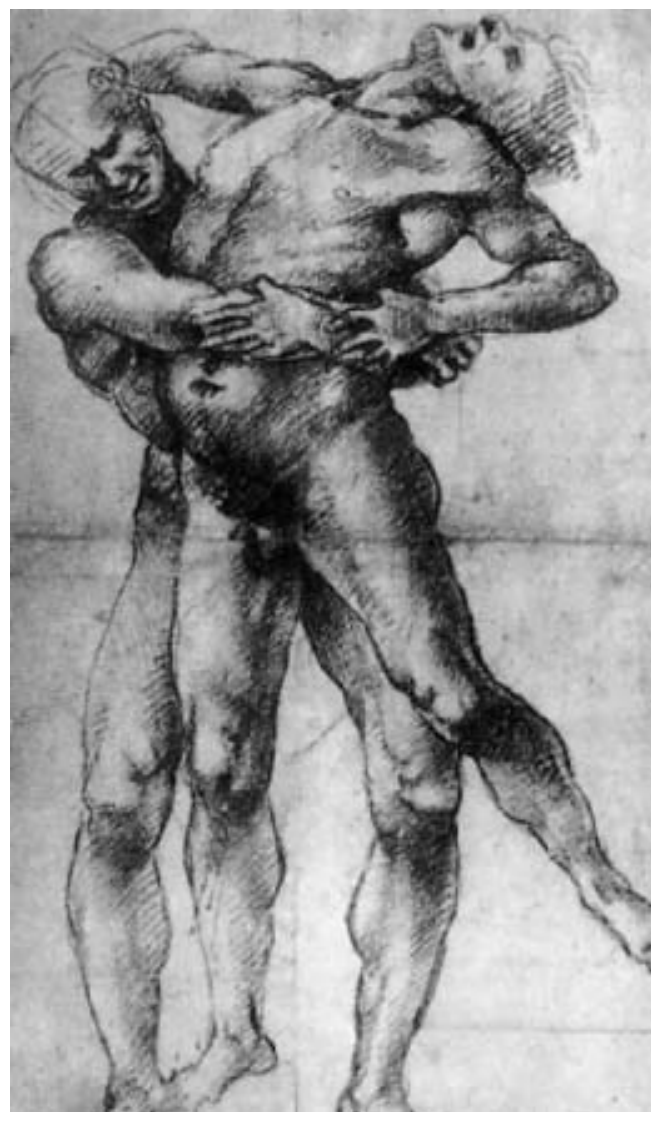

nok ret, og iøvrigt var der jo ikke meget tilbage at engagere sig i, da alle de vidtrækkende storpolitiske beslutninger blev truffet af andre end athenerne selv. Athens politiske svækkelse og afmatning i det fjerde århundrede f.v.t betød selvfølgelig også, at en mulig sammenhæng mellem idræt og politik blev ligegyldiggjort. Dette bevirkede dog ikke, at idrætten i Athen stagnerede. Tværtimod fortsatte udbyggelsen af faciliteterne, konkurrencerne blev udvidet og præmierne bevaret. Idrætten var blevet en fri og uafhængig enhed, der havde værdi, mål og liv i sig selv, og som ikke længere blot var et middel i en højere sags tjeneste. Ironisk nok; mens bystaten mistede pusten militært og politisk vedblev atleterne med 
at klare sig godt ved de olympiske og andre lege. ${ }^{64}$ Denne bibeholdte konkurrenceevne kom i øvrigt også til udtryk i Athensk økonomi og kultur. ${ }^{65}$

\section{Afrunding}

En kort opsummering af de tre faser vedrørende politik og idræt i den Athenske bystat kan lyde således: I takt med fødslen, blomstringen og kollapset af Athen som selvstændig, magtfuld bystat, opstod, svækkedes og forsvandt samspillet mellem idræt og politisk lederskab. Udviklingen gik fra direkte deltagelse i både idræt og politik, hvor det gamle aristokrati med deres medfødte ret til at herske og kæmpe var fremherskende, til et mere indirekte brug, via sponsorater eller deltagelse $i$ hestevæddel $\varnothing b, o g$ til et endeligt hvor idrættens politiske overtoner uigenkaldeligt forsvandt. Såfremt man ønsker at anskue denne udvikling ud fra en anden vinkel, kan vi fremhæve en historisk person nogle hundrede år frem i tiden. Hvad en Alkibiades i 416 f.v.t vandt af politisk medvind via sine berømmelige olympiske sejrer kunne ikke gøres efter af en senere pendant, da Athen var blevet reduceret til en del af et kongerige eller en romersk provins.

\section{Olympias funktion som storpolitisk arena}

Focus vil nu igen blive rettet mere direkte på Olympia i et forsøg på at belyse, om dette fællesgræske mødested spillede nogen rolle i udvekslingen og udbredelsen af sociale og politiske ideer og meninger bystaterne imellem. Det mener Anthony Snodgrass absolut var tilfældet. Snodgrass begrunder sin overbevisning med det påfaldende mønster, der i store træk obser- veres, såfremt man kigger på dannelsen af bystater omkring Ægæerhavet. Disse ensartede, men dog stadigvæk adskilte og selvstændige, stater udviklede sig ikke isoleret, men mere eller mindre parallelt, med en række indbyrdes kontaktflader, der medførte udveksling og overtagelse af varer, kultur, teknik og politiske ideer.

Som eksempler herpå kan nævnes den gradvise udbredelse af det tyranniske styre, ${ }^{66}$ krigsførelse via den militær-strategiske succesfulde hoplitfalanks eller, mere håndgribeligt, imitationen af arkitektur. ${ }^{67}$

Snodgrass mener, at nogle af de vigtige kontaktflader netop var de interstatslige kultsteder, såsom Olympia. Endvidere er han af den mening, at oldtidens grækere til fulde var klar over, hvilken enorm gennemslagskraft udvekslingen af eksempelvis politiske signaler havde netop i forbindelse med en fællesgræsk samling. Markeringer af magtbalancer, militær- og politisk hegemoni blev efterfølgende, via deltagere og tilskuere, båret vidt omkring i store dele af den græske region.

Snodgrass sandsynligg ør, at De Olympiske Lege på flere måder tjente som forum for et sociopolitisk udvekslingspunkt, og selvom han gør opmærksom på, at tyngden $i$ hans egen forskning ligger i tidsperioden 750 - 650 f.v.t, inddrager han dog i flere omgange en række episoder og begivenheder, der befinder sig nogle hundrede år længere fremme i tid, og bevisførelsen kan derfor spaltes i to kategorier.

- Arkæologiske og arkitektoniske fund og indicier.

- Historiske beretninger.

For det første peger Snodgrass på vigtigheden af det forhold, at bystater omkring år 700 f.v.t begyndte at begave Olympia med krigsudstyr såsom hjelme, skjolde m.m. 
Hidtil havde det været reglen, at sådanne ting fulgte den døde i graven. Denne stillen til skue indikerer indledningsvist ikke andet end det forhold, at det ikke længere var nok at være loyal overfor sin familie. Den græske borger skulle også være sin polis en stærk og loyal støtte. Dette blev understreget af denne offentlige udstilling af den dødes krigsremedier, der var de fysiske beviser for en vilje til at kæmpe og ofre sig for sin fødeby. Snodgrass gør dog opmærksom på en bemærkelsesværdig detalje. Tit og ofte var det ikke ens egne våben, man tilegnede Olympia, men derimod våben stammende fra hære og byer, der var blevet besejret. På denne måde afsendte den vindende part et meget kraftigt og håndfast signal vedrørende militær kunnen, der må have imponeret de $\emptyset$ vrige tilstedeværende bystater. $^{68}$

En anden, lidt mindre tydelig markering af en krigssejr, var opstilling af statuer. Messernierne, fra Peloponnes, opstillede således en nu genfunden statue af sejrsgudinden Nike til minde om deres sejr over Sparta i 425 f.v.t. Messernierne afholdt sig dog fra at indhugge en pralende indskrift om, hvem de havde besejret. Ifølge deres eget udsagn fordi de stadig var bange for Sparta. ${ }^{69}$

Der skal bare gives et par eksempler på enkeltpersoner og stater, der, i følge historiske beretninger, anvendte Olympia som et forum for personlig profilering, politisk agitation eller understregning af uændret styrke som selvstændig bystat. Den personlige profilering kan tilskrives Themistokles (525-460 f.v.t), der i forbindelse med De Olympiske lege i 476 f.v.t lod sig hylde som den, der havde reddet både Athen og hele Grækenland fra persisk erobring. Den politiske agitation blev blandt andre ført af Lysias (ca. 460-380). Denne talentfulde taler skulle efter sigende i 388 f.v.t have fremprovokeret et oprør mod ty- rannen Dionysios den ældre (431-367 f.v.t) fra Syrakus på grund af dennes brutalitet og forræderiske opførsel overfor ligesindede grækere i det vestlige. ${ }^{70}$ Hvad angår understregningen af fortsat styrke som uafhængig polis, kan der peges på Athen, som under de opslidende krige mod Sparta offentligt signalerede overskud, i såvel økonomisk som kulturel henseende, ved at anvende offerredskaber af det pureste guld $\mathrm{i}$ forbindelse med ofringerne til Zeus. ${ }^{71}$

De ovenstående eksempler støtter Snodgrass' formodning om, at Olympia var et vigtigt forum for interstatslig sociopolitisk interaktion. Endvidere kastes der lys på den spændende detalje, at disse panhellenske mødesteder var en medvirkende årsag til den ensartede udvikling af de græske bystater, der i grove træk kan observeres indenfor visse områder. Slutteligt dokumenterer Snodgrass' forskning også den iver, hvormed oldtidens grækere kappedes indbyrdes, og den selvtilfredsstillelse de fandt $i$ at udstille egne sejre og andres nederlag. Denne selvtilfredsstillelse kan dog ikke umiddelbart siges at være noget, der afgørende afgrænser oldtidens grækere fra historiens $\emptyset$ vrige samfundsformationer. Det, der adskiller de antikke græske bystaters etnocentriske selvforherligelse fra nutidige eksempler er måden, hvorpå de iscenesættes. ${ }^{72}$ Den åbenlyse anerkendelse af en sejr opnået gennem fysisk vold mod og ødelæggelse af modparten var naturlig i det oldgræske samfund. Der var ingen forsøg på at civilisere kampen og krigen ind i mere sofistikerede og mindre kropslige baner.

\section{Opsamling og perspektivering}

De forløbne sider har diskuteret nogle af de bemærkelsesværdige funktioner Olympia og De Olympiske Lege havde i arkaisk 
og klassisk tid. Denne diskussion har affødt en række mere generelle betragtninger vedrørende relationerne mellem idræt og religion samt idræt og politik i det oldgræske samfund. Denne artikel gør dog ingenlunde krav på at fortælle hele »sandheden«. Dertil er den udvalgte olympiske tidsperiode på godt 400 år simpelthen for omfattende. De følgende konklusioner er derfor ikke endelige, men blot et udtryk for de vigtigste slutninger, der kan drages i denne omgang.

1. I den græske oldtid, der fra midten af det 800 århundrede f.v.t og fremefter blev præget af polis-samfundet, var religion ikke kun et privat anliggende. Religionen blev et af de vigtigste elementer i bestræbelserne på at synliggøre forskelle mellem grupperinger. Som panhellensk helligdom spillede Olympia sin aktive rolle i dette spil.

2. Som årsag til den sammensmeltning mellem idræt og religion, der blandt andet observeres $\mathrm{i}$ forbindelse med De Olympiske Lege, har nogle forfattere peget på, at det nærmest er at betragte som et tilfælde. ${ }^{73}$ Andre mener, idrætten udelukkende var integreret i religiøse samlinger for underholdningens skyld. ${ }^{74}$ En tredje forklaring er den; at deltagerne og tilskuerne via de agonistiske $\emptyset$ velser artikulerede deres tiltro og anerkendelse af guderne og hero'erne. Denne sidste forklaring, kombineret med det faktum at de græske guder var yderst antropomorfe, giver måske det bedste indblik i, hvorfor religion og idræt tit og ofte var uløseligt knyttet sammen i antikken.

3. Årsagen til De Olympiske Leges endeligt var, helt grundlæggende, den polyteistiske oldgræske religion. Lege til de olympiske guders ære måtte naturligvis være uforenelige med det kristne østromerske kejserdømme, og kejser, Theodosius (347-395 e.v.t) (der stærkt medvirkede til indførelsen af kristendommen som statsreligion) forbød derfor i slutningen af 300-tallet e.v.t blandt andet De Olympiske Lege. Muligvis har den græske interesse og dyrkelse af den nøgne krop også med tiden undergravet Olympia's position og levedygtighed. Kirken fordømte nøgenheden, og alt der var forbundet med den, herunder altså også De Olympiske Lege. ${ }^{75}$

4. Indtil afslutningen af de peloponnesiske krige er det i Athen muligt at registrere en anvendelse af idræt i politisk $\emptyset j$ jemed. I minimum én græsk polis blev idrætten altså udnyttet i den interne politiske kamp. Meget tyder på, at succes ved De Olympiske Lege blev opfattet som et af de mere værdifulde midler i bestræbelserne på at opnå politisk indflydelse. Denne sammenhæng mellem idræt og politik er mest tydelig fra det ottende til og med et sted i det sjette århundrede f.v.t. Herefter svækkes den for tilsidst helt at forsvinde omkring den hellenistiske tidsperiodes begyndelse.

5. Ifølge Anthony Snodgrass m.fl. spillede Olympia og dets lege en vigtig rolle som interstatsligt sociopolitisk forum. Samlingen af repræsentanter fra så mange bystater gav rig mulighed for kulturel-, social- og politisk udveksling.

6. Selvom det ikke har været et eksplicit mål med denne artikel, har den alligevel rørt ved et vrangbillede af De antikke Olympiske Lege, der går igen i megen litteratur. Nemlig, at de antikke Olympiske Lege skulle have nogen som helst lighed med De moderne Olympiske Lege. 


\section{Noter}

1. For en diskussion af denne problemstilling se; Young, David C.: Myths about the Ancient Games in Archeology. 1996:49.30 samt Kyle, Donald G.: E. Norman Gardiner: Historian of Ancient Sport i The International Journal of the History of Sport. 1991:8:28-55. Et konkret eksempel på, hvor lang tid denne amatørmyte hang ved, også blandt de mere »oplyste« skribenter, kunne være Lynn og Gray Pooles bog »History of Ancient Olympic Games« fra 1963.

2. Lucas, John.A.: Future of the Olympic Games. 1992, p. 2.

3. De Olympiske Lege blev nedlagt af kejser Theodosius i 393 e.v.t. Alle forfattere er enige om, at kristendommens implementering som statsreligion var den absolutte vigtigste faktor bag legenes ophør.

4. De tolv øverste græske guder, der alle havde sæde på bjergmassivet Olympos. Guderne associeres med årets tolv måneder og de tolv dyrekredstegn og kan kategoriseres i seks par: Zeus og Hera, Poseidon og Demeter, Apollon og Artemis, Ares og Aphrodite, Hermes og Athene, Hephaistos og Hestia. Dionysos regnes nogle gange med i stedet for Hestia. Romerne havde tolv tilsvarende guder: Jupiter og Juno, Neptunus og Ceres, Apollo og Diana, Mars og Venus, Mercurius og Minerva, Volcanus og Vesta.

5. Seltzer, Robert M.(ed.): Religions in Antiquity. 1987.

6. Lademans Religionsleksikon. 1984.

7. Seltzer, Robert M.(ed.): Religions in Antiquity. 1987.

8. Damsgaard-Madsen, Aksel: Grækenlands Historie. 1993.

9. Finley, M.I. og Pleket, H.W.: The Olympic Games the first thousand years. 1976, p. 18.

10. Seltzer, Robert M.(ed.): Religions in Antiquity. 1987.

11. Der jo strengt taget betyder det højeste sted i byen.

12. Sourvinou-Inwood, Christiane: What is Polis Religion?. 1991.

13. Mckay, John P. et al.: History og Western Society. 1995.

14. Sourvinou-Inwood, Christiane: What is Polis Religion?. 1991, p. 304.

15. Seltzer, Robert M.(ed.): Religions in Antiquity. 1987.

16. Hero'erne var, som nævnt, mennesker og ikke guder. Dette muliggjorde, at grækere i arkaisk-, klassisk- eller anden tid kunnne gøre sig forhåbninger om, at deres gerninger kunne berettige dem til en plads blandt de næsten-guddommelige. Et eksempel på en idrætsmand, der kom så langt, er Theagenes fra bystaten Thasos. Han vandt den olympiske boksekonkurrence i 480 f.v.t., og i 476 f.v.t. triumferede han i den yderst voldsomme hybrid mellem brydning og boksning - pankration. Theagenes fik registreret over 1400 sejre i løbet af sin lange karriere. Efter hans død blev der i fødebyen opstillet en statue af den berømte atlet, der efterfølgende dannede fikspunkt for en hero-kult. Der er dog kun ganske få eksempler på personer, der (altid efter deres død) blev heroniseret.

17. Bendtsen, Margit et al.: Den Græske Olympiade. 1980.

18. Morgan, Catherine: Athletes and Oracles. 1990.

19. Ibid.

20. Damsgaard-Madsen, Aksel: Grækenlands Historie. 1993.

21. Hjorts $\varnothing$, Leo: Den Græske Olympiade. 1980.

22. Finley, M.I. og Pleket, H.W.: The Olympic Games the first thousand years. 1976, p. 15.

23. Fejfer, Jane et al.: Sport og Samfund. 1981, p. 22.

24. Hellenisme anvendes normalt om den kultur, der udvikledes i Alexander den Stores verdensrige, og i de stater der blev konsekvensen af dette imperies sammenbrud. Tidsrummet er cirka 330-30 f.v.t.

25. Et andet eksempel på den vægt grækerne lagde på dette, at være den første og den fremmeste, kan hentes fra den måde hvorpå man opdelte deltagerne ved De Olympiske Lege. I dag - ved de moderne Olympiske Lege eksempelvis - mener man det $i$ kampsportene nødvendigt at inddele $i$ adskillige og vel afgrænsede klasser, således at konkurrencen bliver »fair«. En sådan tankegang ville en atlet fra antikken stille sig aldeles uforstående overfor. Han ville understrege, at kun den absolutte triumf blandt alle (frie) deltagere/borgere var noget værd. En sejr blandt en gruppe af underlegne mænd var ligegyldig. På baggrund af dette skelnedes der ved De antikke Olympiske Lege kun mellem drenge og mænd. Deltagerne blev efterfølgende opdelt i disse to grove kategorier.

26. Finley, M.I. og Pleket, H.W.: The Olympic Games the first thousand years. 1976 .

27. Ibid.

28. Braarvig, Jens: Spranget fra døden til livet: Idrett i det arkaiske Hellas in Samtiden nr.1. 1994.

29. Ibid., p. 10.

30. Nielsen, Niels Kayser: Sundhed og sport - træning, opdragelse, dannelse?. Upubliceret manus. 
31. Kyle, Donald G.: Athletics in acient Athens. 1987.

32. Hvor de (rige) unge mænd blev skolet med en, for os, fremmed blanding af musik, medicin og idræt.

33. Hjortsø, Leo: Den Græske Olympiade. 1980.

34. Glanell, Thomas og Strömberg, Robert: Antikkens Olympiska Spel. 1991.

35. Bendtsen, Margit et al.: Den Græske Olympiade. 1980.

36. Fejfer, Jane et al.: Sport og Samfund. 1981, p. 14.

37. Bendtsen, Margit et al.: Den Græske Olympiade. 1980.

38. Glanell, Thomas og Strömberg, Robert: Antikkens Olympiska spel. 1991.

39. Bendtsen, Margit et al.: Den Græske Olympiade. 1980.

40. Finley, M.I. og Pleket, H.W.: The Olympic Games the first thousand years. 1976.

41. Ibid., p. 22.

42. Det skal nævnes, at sålænge den olympiske fred var i kraft, måtte ingen stat erklære åben krig mod elæerne. Elæerne måtte så til gengæld heller ikke begynde en konflikt. Det kan altså hævdes, at den olympiske fred - aktivt - hindrede krigshandlinger. På den anden side kan betydningen af det nævnte diskuteres. For det første hørte bystaten Elis absolut ikke til de mere aggressive og stridlystne af slagsen, og for det andet kunne denne ikke-angrebs pagt nok ikke forventes at forhindre stridigheder, men allerhøjest udskyde dem.

43. Ibid.

44. Bendtsen, Margit et al.: Den Græske Olympiade. 1980.

45. Finley, M.I. og Pleket, H.W.: The Olympic Games the first thousand years. 1976.

46. Ibid.

47. Kyle, Donald G.: Athletics in acient Athens. 1987.

48. Ibid.

49. Matz, David: Greek and Roman sport. 1991.

50. Damsgaard-Madsen, Aksel: Grækenlands Historie. 1993.

51. Ibid.

52. Kyle, Donald G.: Athletics in acient Athens. 1987.

53. Damsgaard-Madsen, Aksel: Grækenlands Historie. 1993.

54. Kyle, Donald G.: Athletics in acient Athens. 1987. 55. Ibid.

56. Der kan dog altid findes undtagelser fra en sådan generel tendens og for god ordens skyld skal der peges på en enkelt person, som i denne periode opnåede både atletisk berømmelse og politisk indflydelse. Bryderen Callias vandt både olympiske-, pythiske-, nemæiske og isthmiske lege og efter sin imponerende karriere engagerede han sig aktivt i Athens politiske liv.

57. Finley, M.I. og Pleket, H.W.: The Olympic Games the first thousand years. 1976.

58. Matz, David: Greek and Roman sport. 1991.

59. Damsgaard-Madsen, Aksel: Grækenlands Historie. 1993

60. Kyle, Donald G.: Athletics in acient Athens. 1987.

61. Damsgaard-Madsen, Aksel: Grækenlands Historie. 1993.

62. Kyle, Donald G.: Athletics in acient Athens. 1987.

63. Damsgaard-Madsen, Aksel: Grækenlands Historie. 1993.

64. Kyle, Donald G.: Athletics in acient Athens. 1987.

65. Damsgaard-Madsen, Aksel: Grækenlands Historie. 1993.

66. Hermed ikke sagt, at indførelsen af tyranni blot skyldtes et $\emptyset$ nske om at ligne de andre bystater mest muligt. Pointen er bare, at ideen til indførelse af tyrraniet kunne tænkes at være opstået i forbindelse med en sammenligning af hjemstavns polis med en eller flere andre. Eksempelvis kan det tænkes, men aldrig bevises, at omtalte Kylon fik sin tyranniske inspiration fra kypselidernes (tyrannen Kypselos og sønnen Peiandros. Regerings periode ca. 655-625 f.v.t.) succes i Korinth.

67. Renfrew, Colin et al.: Peer polity interaction and socio-political change. 1986.

68. Ibid.

69. Bendtsen, Margit et al.: Den Græske Olympiade. 1980.

70. Renfrew, Colin et al.: Peer polity interaction and socio-political change. 1986.

71. Bendtsen, Margit et al.: Den Græske Olympiade. 1980.

72. Dunning, Eric. G. (ed.): The sports Process - A comparative and developmental approach. 1993.

73. Harris, H.A.: Sport in Greece and Rome.1972.

74. Gardiner, E. Norman: Greek Athletic Sports and Festivals. 1910.

75. Finley, M.I. og Pleket, H.W.: The Olympic Games the first thousand years. 1976 . 


\section{Litteraturliste}

Bendtsen, Margit et al.: $1980 »$ Den Græske Olympiade«. Sfinx.

Braarvig, Jens: 1994 »Spranget fra døden til livet: Idrett i det arkaiske Hellas«. Samtiden, 1.

Damsgaard-Madsen, Aksel: 1993 »Grækenlands Historie«. Aarhus Universitetsforlag.

Due, Bodil: $1980 »$ Olympisk Festlyrik«. Sfinx, 2.

Dunning, Eric G. (Red.): 1993 »The Sports Process A comparative developmental approach «. Human Kinetics Publishers

Fejfer, Jane et al.: $1981 »$ Sport og Samfund«. Sfinx.

Finley, M.I og Pleket, H.W.: »The Olympic Games the first thousand years «. London.

Gardiner, E. Norman: 1910 »Greek Athletic Sports and Festivals«. London.

Glanell, Tomas og Strömberg, Robert: 1991 »Antikkens Olympiska Spel«. Athen.

Harris, H.A.: 1972 »Sport in Greece and Rome«. Cornell University Press.

Hjortsø, Leo: 1980 »Den Græske Olympiade«. Sfinx, 2.

Kyle, Donald G.: 1987 »Athletics in Ancient Athens «. Leiden E.J.Brill.

Kyle, Donald G.: 1991 »E. Norman Gardiner: Historian of Ancient Sport«. The International Journal of the History of Sport, 8:1:28-55.
Kyle, Donald G.: 1996 »Winning at Olympia«. Archaeology, 49:26-37.

Lucas, John A.: 1992 »Future of the Olympic Games«. Human Kinetics Books.

Matz, David: 1991 »Greek and Roman Sports«. Mcfarland.

Mckay, John P. et al.: 1995 »A History of Western Society«. Houghton Mifflin Company.

Morgan, Catherine: 1990 »Athletes and Oracles«. Cambridge University Press.

Nielsen, Niels K.: Upubliceret manus »Sundhed og Sport - træning, opdragelse, dannelse?«. Odense.

Poole, Gray og Poole, Lynn: 1963 »History of Ancient Olympic Games«. New York.

Renfrew, Colin et al.: 1986 »Peer polity interaction and socio-political change«. Cambridge University Press.

Scanlon, Thomas F.: $1996 »$ Games for Girls«. Archaeology, 49:32-33.

Seltzer, Robert M.: 1987 »Religions of Antiquity«. Macmillan Publishing Company.

Sourvinou-Inwood, Christiane: $1990 »$ What is Polis Religion?«. Cambridge.

Young, David C.: 1996 »Myths about the Ancient Games«. Archaeology, 49:30. 